\title{
Green Stink Bug, Acrosternum hilare (Say) (Insecta: Hemiptera: Pentatomidae) ${ }^{1}$
}

\section{Celina Gomez and Russell F. Mizell III \\ Introduction}

The green stink bug, Acrosternum hilare (Say), is a commonly encountered pest of seeds, grain, nuts and fruit in both the nymph and adult stages across North America. This species is highly polyphagous (has many host plants) which it damages through feeding. While capable of long distance movements to find food, the bugs are most often clumped around host plants in the optimum stage of development.

\section{Distribution}

The green stink bug occurs in most of eastern North America, from Quebec and New England west through southern Canada and northern U.S. to the Pacific Coast, and southwest from Florida through California. This is the most commonly encountered stink bug species in North America. However, in Florida other stink bug species often reach higher populations than A. hilare.

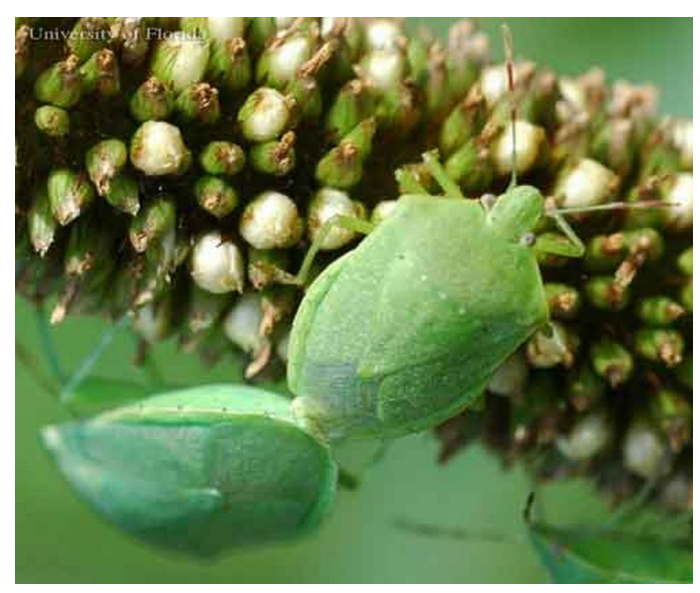

Figure 1. Adult green stink bugs, Acrosternum hilare (Say), on millet. Credits: Russell F. Mizell, III, University of Florida

\section{Description}

The green stink bug, A. hilare, may be confused with the southern green stink bug, Nezara viridula (Linnaeus), but can be distinguished easily by its longate ventral ostiolar canal (external outflow pathway of metathoracic scent gland), which extends well beyond the middle of its supporting plate, while

\footnotetext{
1. This document is EENY-431, one of a series of Featured Creatures from the Entomology and Nematology Department, Florida Cooperative Extension Service, Institute of Food and Agricultural Sciences, University of Florida. Published: February 2009. This document is also available on Featured Creatures Web site at http://entomology.ifas.ufl.edu/creatures. Please visit the EDIS Web site at http://edis.ifas.ufl.edu. Additional information on these organisms, including many color photographs, is available at the Entomology and Nematology Department Web site at http://entnemdept.ifas.ufl.edu/.

2. Celina Gomez, undergraduate intern, North Florida Research and Education Center (REC)-Quincy FL; Russell F. Mizell III, assistant program director and professor, North Florida REC-Quincy FL; Florida Cooperative Extension Service, Institute of Food and Agricultural Sciences, University of Florida, Gainesville FL 32611.
}

The Institute of Food and Agricultural Sciences (IFAS) is an Equal Opportunity Institution authorized to provide research, educational information and other services only to individuals and institutions that function with non-discrimination with respect to race, creed, color, religion, age, disability, sex, sexual orientation, marital status, national origin, political opinions or affiliations. U.S. Department of Agriculture, Cooperative Extension Service, University of Florida, IFAS, Florida A. \& M. University Cooperative Extension Program, and Boards of County Commissioners Cooperating. Millie Ferrer-Chancy, Interim Dean 
that of $\mathrm{N}$. viridula is shorter and does not reach the middle of its supporting plate.
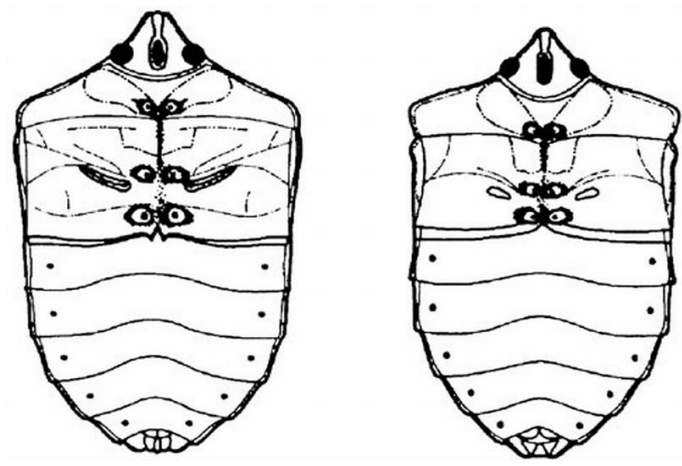

Figure 2. Ventral surface of stink bugs. Scent gland location near base of middle legs, elongate (left) and not elongate (right).

Adults: Like other stink bugs, adult green stink bugs are shield-shaped with fully developed wings. They are solid light green and measure 14 to $19 \mathrm{~mm}$ in length. The head and pronotum frequently are bordered by a narrow, orange-yellow line. Both adults and nymphs have piercing and sucking mouthparts for removing plant fluids.

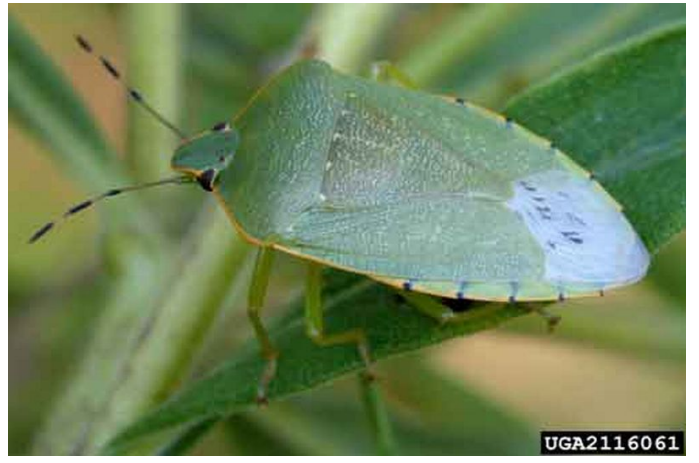

Figure 3. Dorsal view of an adult green stink bug, Acrosternum hilare (Say). Credits: David Cappaert, Michigan State University, Bugwood.org

Eggs: When first laid, the eggs of the green stink bug are yellow to green, later turning pink to gray. The eggs are placed in clusters that appear as double rows of small barrels on and around suitable food, and are usually attached to the underside of leaves. They measure 1.4 by $1.2 \mathrm{~mm}$.

Nymphs: The nymphs are predominantly black when small, but as they approach adulthood, they become green, and yellow or red. However, the immature stages have a distinctive pattern of whitish spots on the abdominal segments. Their bodies are oval-shaped, and they also have short and

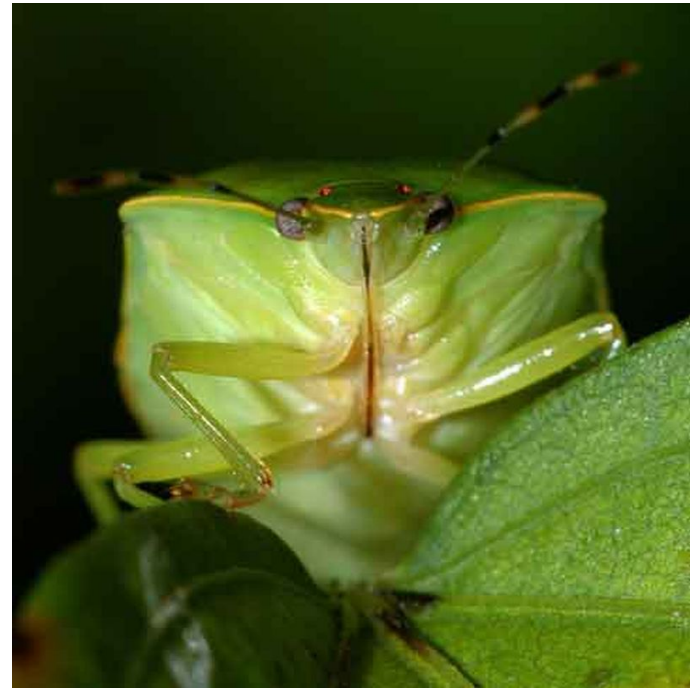

Figure 4. Frontal view of an adult green stink bug, Acrosternum hilare (Say). Credits: Susan Ellis, Bugwood.org

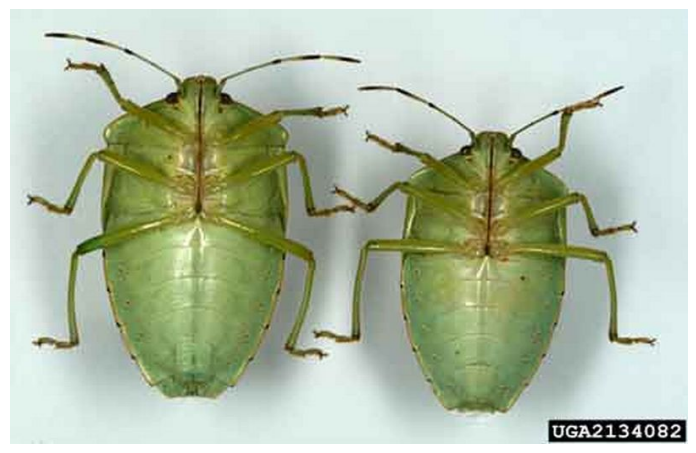

Figure 5. Ventral view of adult female (left) and male (right) green stink bugs, Acrosternum hilare (Say). Credits: Herb Pilcher, USDA-ARS, Bugwood.org

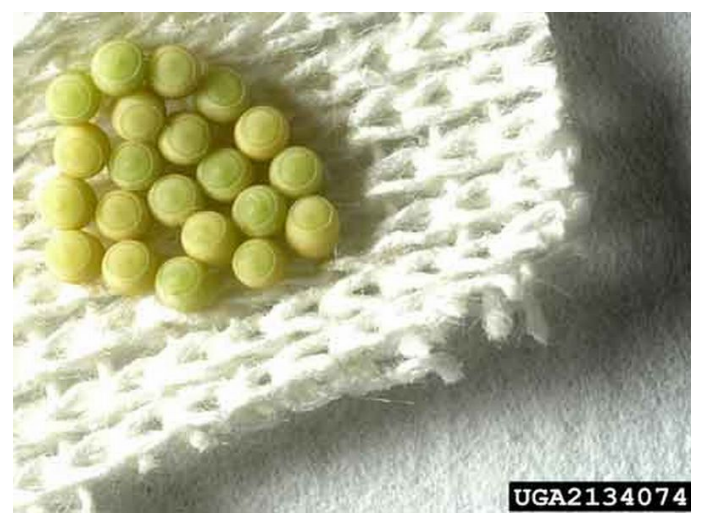

Figure 6. Newly laid eggs of the green stink bug, Acrosternum hilare (Say). Credits: Herb Pilcher, USDA-ARS, Bugwood.org

nonfunctional wing pads which, once they reach the final instar, makes them look somewhat like adults. Several instars are often found together in high numbers because of stink bug oviposition behavior. 


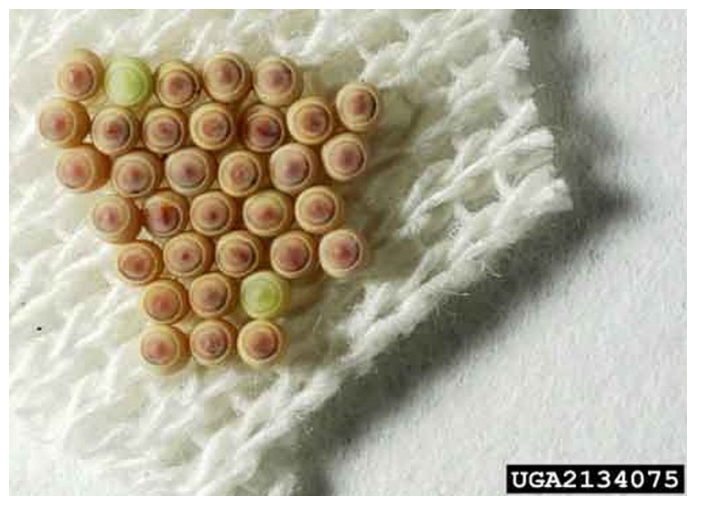

Figure 7. Five-day-old eggs of the green stink bug, Acrosternum hilare (Say). Credits: Herb Pilcher, USDA-ARS, Bugwood.org

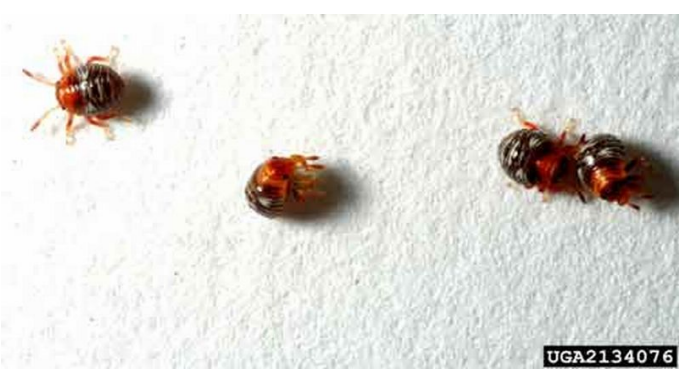

Figure 8. First instar nymph of the green stink bug, Acrosternum hilare (Say). Credits: Herb Pilcher, USDA-ARS, Bugwood.org

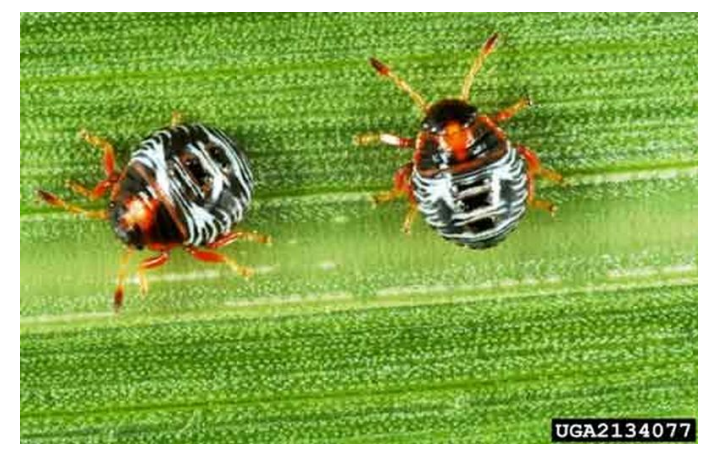

Figure 9. Second instar nymph of the green stink bug, Acrosternum hilare (Say). Credits: Herb Pilcher, USDA-ARS, Bugwood.org

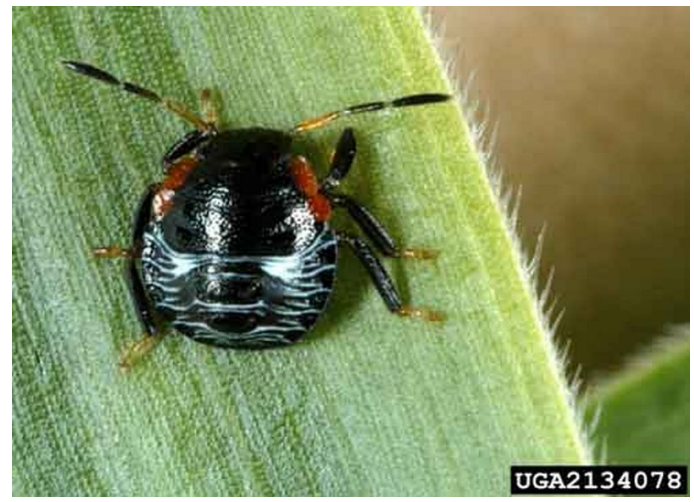

Figure 10. Third instar nymph of the green stink bug, Acrosternum hilare (Say). Credits: Herb Pilcher, USDA-ARS, Bugwood.org

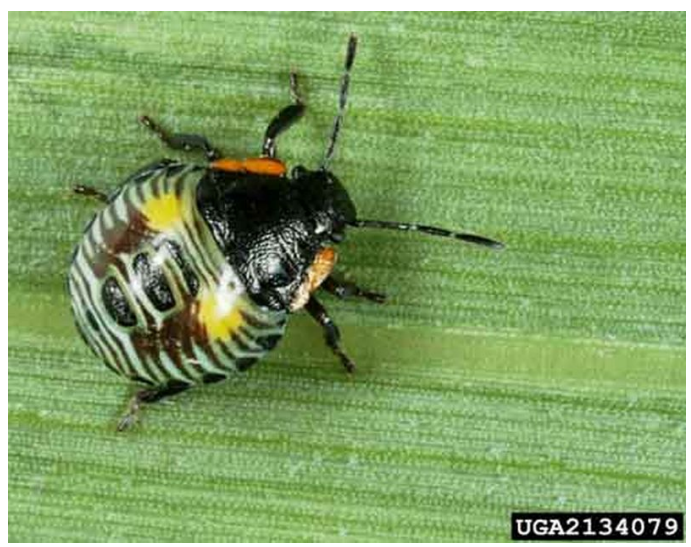

Figure 11. Fourth instar nymph of the green stink bug, Acrosternum hilare (Say). Credits: Herb Pilcher, USDA-ARS, Bugwood.org

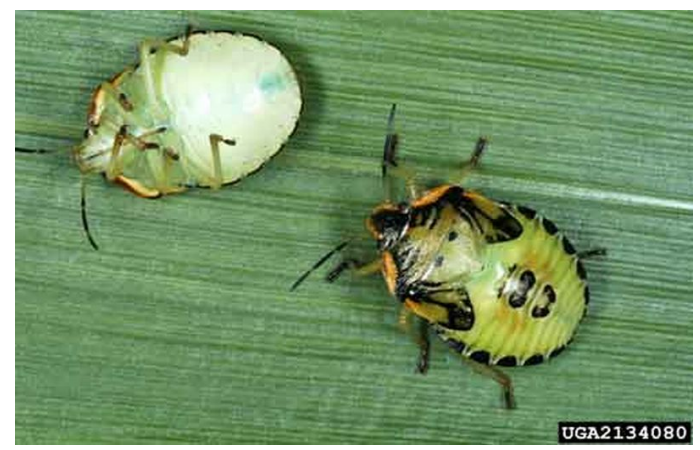

Figure 12. Fifth instar nymph of the green stink bug, Acrosternum hilare (Say). Credits: Herb Pilcher, USDA-ARS, Bugwood.org

\section{Life Cycle and Biology}

Green stink bugs become active during the first warm days of spring and this is when mating occurs. A few bugs may be present from May through June, but are more common in mid to late June and taper off in fruit trees in July and August with only one 
generation per year. A second generation may occur in July and August.

The life cycle typically takes 30 to 45 days. The normal development from egg to adult requires about 35 days, but varies with temperature. As with other Hemipterans, the green stink bug has an incomplete metamorphosis, which means that the immature resemble the adults. Undeveloped stages go through five instars, and each time a nymph molts it looks a little more like an adult; this process takes the insect about a month.

Oviposition may occur anytime when adults are present from May through July and August. Eggs hatch in about a week. There is a significant positive relationship between female body size and fecundity. The green stink bug is univoltine (one generation a year) in northern areas and bivoltine (two generations) in its southern range reflecting their reaction to the differences in environmental conditions.

If the weather stays warm, an adult stinkbug lives about two months. During cold weather, young stink bugs will hibernate in leaf litter or under tree bark until the onset of warmer temperatures.

Laboratory experiments have demonstrated that females choose to mate with large males, while males prefer to mate with larger females. Males have direct reproductive gain by choosing larger females, but the advantages to females are not clear.

\section{Hosts}

A sequence of host plants with overlapping periods of seed and fruit production is necessary for A. hilare to develop large populations during its annual life cycle.

Acrosternum hilare is an important pest because it is has a broad range of suitable hosts. Some of its favorite hosts are black cherry and elderberry, flowering dogwood, evergreen blackberry, basswood, and pine trees. The species also attacks a large number of important economic crops, including cotton, soybean, tobacco, pear, apricot, asparagus, apple, cherries, peach, eggplant, tomato, beans, peas, and corn.

\section{Damage}

The green stink bug attacks the developing fruits of several cultivated trees, and the type of damage varies with the age of the developing fruit - the earlier feeding occurs in the development of the fruit, the more severe the damage. Injuries are usually caused by adults as the nymphs are not mobile enough to move to early-producing fruit trees like peaches or nectarines. However, in grapes, adults often lay eggs early in the season and the small nymphs will begin to suck the juices out of the maturing fruit.

While feeding, the green stink bugs inject digestive enzymes into food that liquefies the contents which they then feed upon. This action reduces the quality of the fruit or seed. The feeding wound also provides an opportunity for pathogens to gain entry.

Catfacing, which is the most severe injury to fruit such as peach, is characterized by sunken areas surrounded by distorted tissues. The surfaces are rough, corky and lack pubescence, because the tissue at the site of the feeding puncture stops growing whereas those surrounding the site do not. Another type of damage by the green stink bug is called dimpling or scarring, which is a slight depression caused by the shrinkage of the tissues injured by the feeding of the bugs. Nymphs sometimes cause considerable damage in the form of dimples. It has been shown that the most severe damage occurs in the vicinity of woodlands.

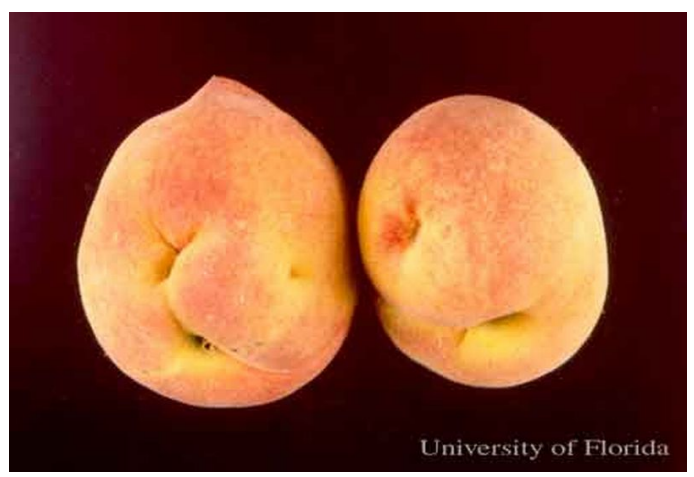

Figure 13. Catfacing on peach caused from feeding by the green stink bug, Acrosternum hilare (Say). Credits: Russell F. Mizell, III, University of Florida 


\section{Management}

Chemical control. Insecticide application for control of stink bugs in many crops is often warranted.

Insect Management Guide for fruit trees

Insect Management Guide for vegetables

Insect Management Guide for field crops

Insect Management Guide for ornamentals

Biological control. Green stink bugs have numerous natural enemies. Birds, toads, spiders, other insect-eating animals and even other insects prey on them. . The various life stages of the green stink bug may be parasitized by species of Hymenoptera and Diptera.

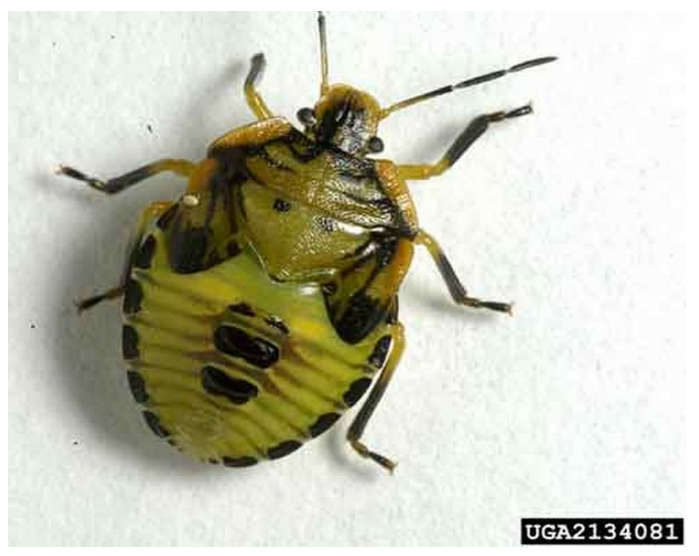

Figure 14. Egg of Tricopoda pennipes, a tachinid parasitic fly, on left wing pad of a 5th instar nymph of the green stink bug, Acrosternum hilare (Say). Credits: Herb Pilcher, USDA-ARS, Bugwood.org

\section{Selected References}

McPherson JE. 1982. The Pentatomoidea (Hemiptera) of Northeastern North America with Emphasis on the Fauna of Illinois. Southern Illinois University Press. IL. pp. 86-89

McPherson JE, McPherson RM. 2000. Stink Bugs of Economic Importance in America North of Mexico. CRC Press. Boca Raton, Florida. pp. 129-139

Mizell RF. (2008). Monitoring stink bugs with the Florida stink bug trap. Insect Traps and Sampling. http://ufinsect.ifas.ufl.edu/stink_bugs/stink_bugs.htm (3 April 2008).

Mizell RF. (2005). Stink bugs and leaffooted bugs are important fruit, nut, seed and vegetable pests. EDIS. UF/IFAS. ENY-718. http://edis.ifas.ufl.edu/IN534 (3 April 2008).

North Carolina State University Cooperative Extension. Stink Bugs. North Carolina Integrated Pest Management Information.

http://ipm.ncsu.edu/AG271/soybeans/stink_bugs.html (3 April 2008).

Pickel C, Bentley WJ, Hasey JK, Day KR, Rice RE. (2006). Peach Stink Bugs. UC IPM Online. http://www.ipm.ucdavis.edu/PMG/r602300111.html (3 April 2008).

Slater JA, Baranowski RM. 1978. How to Know the True Bugs. Wm. C. Brown Company Publishers. pp 50. 